Authors' reply: We are grateful for the opportunity to respond to Dr Calton. He challenges claims for objectivity in the diagnosis of any disorder that has an interpersonal component, taking as his example some research into the diagnosis of personality disorder. He queries why we do not consider the role of the therapist's personality in our paper, 'Objectivity in psychoanalytic assessment of couple relationships' (Lanman et al, 2003). In that paper, where we show evidence of a good degree of objectivity (based on interrater reliability) for the diagnoses we discuss, we specifically refer to the fact that those making the judgements need to have had a psychoanalytically based training in order to develop their ability to make use of their emotional reactions to the patient.

Our paper deals with psychotherapeutic diagnoses, rather than with psychiatric ones, but on the basis of our work we would like to comment on Dr Calton's position. First, there are likely to be very significant differences in what is judged to be a helpful 'fit' between therapist and patient, between the two different domains of general psychiatry and psychoanalytic psychotherapy. In the former, a friendly and sympathetic stance may be the crucial therapeutic vehicle for providing medication and other treatments. But in the domain of psychotherapy it is not necessarily a good thing to 'match' therapist to patient, if by this one means attempting to avoid prejudices or sensitive areas, because this is likely to lead to a serious evasion of the darker areas of interaction, conscious and unconscious, where the significant problems will tend to lie. If the study of the interaction 'in the room', between therapist and patient, is itself the treatment, then the therapist's best equipment for this is self-knowledge, including knowledge of the darker areas of his or her own personality and knowledge of how to recognise and use the ways in which these affect him or her.

While personal psychotherapy together with detailed supervision by no means guarantee the development of such knowledge and there will be practitioners who are unable to respond, as well as therapies which do not go far enough - these remain the best available means of acquiring the skills necessary to work with unconscious processes, enabling a therapist to understand a patient's personality difficulties of and the way these interact with their own. Outside this particular field, it may not be widely recognised that one of the principal tools of contemporary psychoanalytic therapy is the constant monitoring by practitioners of their own emotional responses to patients, not simply in order to suppress or redirect them, but in order to gain information that the therapist will then be able to employ in clinical diagnosis and engagement with patients. This is not to be confused with the self-disclosure advocated by some therapies. In our view there is no substitute for a rigorous psychotherapeutic training in this area, which includes selection of trainees, personal psychotherapy and detailed supervision.

Lanman, M., Grier, F. \& Evans, C. (2003) Objectivity in psychoanalytic assessment of couple relationships. British Journal of Psychiatry, I82, 255-260.

F. Grier, M. Lanman, C. Evans Tavistock Menta Studies Institute, The Tavistock Centre, 120 Belsize Lane, London NW3 5BA, UK

\section{Creativity and mental health}

After thoroughly enjoying Dr Wills' 1988 book (Wills \& Cooper, 1988) I was dismayed to see his recent article (Wills, 2003). His book detailed the real, unremitting and often unique stressors faced by those struggling to make a living from music - as opposed to the pop-psychology focus on their (allegedly) inherent psychological flaws.

Although entertaining, psychological autopsies are not valid research tools, as the author fortunately points out in the 'limitations' box. Further, the 'comprehensive literature' about the psychopathology/ creativity link is shot through with badly designed studies and dramatic overstatement.

Like Wills, Jamison (1989) was the sole judge of her hand-picked sample - 47 creative artists - but few authors dig up her unreplicated original work, preferring to pass along her unscientific conclusions. For example, many introductory psychology textbooks include her contention that $50 \%$ of poets have affective disorders, without noting that she had only 18 poets in her sample and moreover diagnosed affective disorder as simply 'seeking treatment' for it. And while Ludwig's book (1995) is full of charts and graphs, on close and trained inspection they are overwhelmingly meaningless; despite its subtitle, it actually resolves nothing at all.

Unfortunately, the tradition in this field is to pass along any confirmatory 'mad creative' conclusions, regardless of any liberties taken with the scientific method.
Most of the common research blunders are detailed by Arnold Rothenberg (1990), as well as in my own work (Schlesinger, $2002 a, b)$. Such flaws should have been fatal, but apparently the public appetite for the doomed artist is too great. It's a shame that so many professionals continue to feed it with their invalid speculation. As Wills understands better than most, musicians don't need anything else to worry about.

Jamison, K. R. (1989) Mood disorders and patterns of creativity in British writers and artists. Psychiatry, $\mathbf{5 2}$ 125-134.

Ludwig, A. M. (1995) The Price of Greatness: Resolving the Creativity and Madness Controversy. New York: Guilford Press.

Rothenberg, A. (1990) Creativity and Madness: New Findings and Old Stereotypes. Baltimore, MD: Johns Hopkins University Press.

Schlesinger, J. (2002a) Issues in creativity and madness: part one, ancient questions and modern answers. Ethical Human Sciences and Services: An International Journal of Critical Inquiry, 4, 73-76.

Schlesinger, J. (2002b) Issues in creativity and madness: part two, eternal flames. Ethical Human Sciences and Services: An International Journal of Critical Inquiry, 4 . 139-142.

Wills, G. \& Cooper, C. L. (1988) Pressure Sensitive: Popular Musicians under Stress. London: Sage.

Wills, G. (2003) Forty lives in the bebop business: mental health in a group of eminent jazz musicians. British Journal of Psychiatry, 183, 255-259.

J. Schlesinger 300 Broadway, Suite 3B, Dobbs Ferry, New York 10522, USA

Author's reply: Schlesinger feels that 'psychological autopsies are not valid research tools', and is scathingly critical of the work of Jamison (1989) and Ludwig (1995). However, she fails to take into account the conclusions of Jamison's later work (1993), which, as well as reporting on her own study of 47 contemporary British writers and artists, also discusses biographical material relating to 195 famous artistic creative persons, $21.5 \%$ of whom died by suicide and $33.3 \%$ of whom were hospitalised with psychiatric problems. Jamison also refers to many academic studies of creativity and mental illness stretching back over the past century.

Turning to what Schlesinger describes as Ludwig's 'overwhelmingly meaningless' charts and graphs, I have to say that I find his statistics perfectly acceptable and meaningful. The use of psychological autopsies is a legitimate exercise if one follows rigorous 